\title{
Tata Kelola Pramuwisata Khusus Sebagai Bentuk Pelibatan Masyarakat Lokal
}

\author{
Ely Triasih Rahayu ${ }^{1}$, Bagus Reza Hariyadi ${ }^{2}$, Hartati ${ }^{3}$, \\ Anggita Stovia ${ }^{4}$, Anak Agung Ayu Dian Andriyani ${ }^{5}$ \\ Universitas Jenderal Soedirman, Jl. Profesor DR. HR Boenyamin No.708, Dukuhbandong, \\ Grendeng, Kec. Purwokerto Utara, Kabupaten Banyumas, Jawa Tengah 53122 1,2,3,4 \\ Universitas Mahasaraswati, J1. Kamboja No.11A, Dangin Puri Kangin, Kec. Denpasar Utara, Kota \\ Denpasar, Bali $80233^{5}$ \\ Email: ely.rahayu@unsoed.ac.id ${ }^{1 *}$
}

\begin{abstract}
ABSTRAK
Adanya regulasi Dinas Pariwisata Propinsi Bali mengenai kebijakan pengkategorian pramuwisata umum dan khusus menimbulkan permasalahan baru. Permasalahan yang muncul adalah makin berkembangnya pramuwisata ilegal (non formal) yang tidak memiliki Kartu Tanda Pengenal Pramuwisata (KTPP). Pramuwisata illegal tidak hanya dilakukan oleh orang Indonesia yang memiliki kemampuan berbahasa asing, tetapi juga dilakukan oleh wisatawan asing yang sudah mengenal pariwisata Bali karena sering melakukan kunjungan ke Bali. Permasalahan yang lain adalah tidak adanya pelimpahan tugas dari pramuwisata umum ke khusus. Pramuwisata umum di Bali adalah pramuwisata yang bekerja di tingkat provinsi, sedangkan pramuwisata khusus adalah pramuwisata yang bekerja di daerah tujuan wisata di tingkat kabupaten. Penyebab permasalahan ini karena tidak adanya regulasi yang berupa peraturan Bupati untuk mengatur pramuwisata khusus. Di Bali terdapat Peraturan Daerah No. 5 Tahun 2016 yang mengatur pramuwisata secara umum, tetapi di tingkat kabupaten belum dilakukan kajian pramuwisata khusus sehingga pembagian kerja antara pramuwisata umum dan khusus tidak jelas. Ketidakjelasan inilah yang menyebabkan banyak permasalahan yang muncul terutama di daerah tujuan wisata tingkat kabupaten. Tim Pengabdian kepada Masyarakat (PKM) melakukan pengabdian di kabupaten Bangli dengan pertimbangan bahwa kabupaten ini merupakan salah satu kabupaten yang memiliki kontribusi besar bagi income daerah pada sektor pariwisata. Kabupaten Bangli merupakan salah satu kabupaten yang siap menelaah Peraturan Daerah nomor 5 tahun 2016 yang kemudian diturunkan menjadi peraturan Bupati Bangli mengenai tata kelola pramuwisata khsusus. Kegiatan PKM ini bertujuan untuk mengiventarisir ecxiting codition dikaitkan dengan permasalahan yang ada. Hasil dari inventarisir ini dijadikan landasan dalam membuat model tata kelola pramuwisata khusus. Model tata kelola pramuwisata diusulkan kepada Bupati Bangli sebagai landasan pembuatan peraturan Bupati tentang pramuwisata khusus.
\end{abstract}

Kata Kunci: Pariwisata, Pramuwisata Khusus, Tata Kelola, Desa Wisata

\begin{abstract}
The regulation issued by the Bali Province Tourism Office on policy related to the categorization of both general and special tour guides resulted in new problems. The arising problems included the recently growing illegal (non-formal) tour guides without a Tour Guide Identity Card. Illegal Tour guides were not only performed by the Indonesian people with foreign language competencies but also foreigners familiar with Bali tourism and frequently visited Bali. The other problem was related to the entrustments from the general to the special tour guides. The general tour guides in Bali are those working at the provincial level, while special tour guides are those working in the tourism destinations at regency level. These arising problems were due to the inexistence of regulation in the form of Regent Regulation to regulate the special tour guides. The Regional Regulation No. 5 Year 2016 only regulates the general tour guides, yet the special tour guides have not been discussed, thus, there is no clear division of duties for the general and special tour
\end{abstract}


guides in Bali and results in various problems in the tourism destinations at regency level. The Community Service Team has made various community services in Bangli Regency by considering that this regency has a great contribution to its regional income, especially in tourism sector. Bangli is a regency which is ready to review and downgrade the Regional Regulation No. 5 Year 2016 into Bangli Regent Regulation on Special Tour Guide Management. The purpose of this community service is to inventory the existing problems, formulate a special tour guide management model, and propose the model to the Bangli Regency as a basic reference in formulating the Regent Regulation on Special Tour Guides.

Keywords: Tourism, Special Tour Guide, Management, Tourist Village

\section{PENDAHULUAN}

Prospek kepariwisataan dalam struktur pembangunan nasional, membentuk dorongan dan keharusan akan langkah-langkah strategis dalam meningkatkan kinerja kepariwisataan nasional, maupun peningkatan daya saing sehingga dapat menarik kunjungan wisatawan mancanegara dan pergerakan wisatawan domestik yang semakin merata serta ketertarikan dalam investasi yang semakin tinggi di Indonesia. Hal ini sangat berdampak terhadap nilai manfaat ekonomi yang terdampak sektor pariwisata. Pariwisata memberikan dampak yang luas terhadap pembangunan nasional juga kesejahteraan masyarakat.

Kementerian Pariwisata indonesia pada tahun 2018 mencatat pemasukan dari sektor pariwisata yang mencapai US\$ 19,29 miliar, dimana hampir mendekati target yang ditetapkan Presiden Jokowi untuk tahun 2019 yaitu US\$ 20 miliar. Data bersumber pada jumlah kunjungan wisman berdasarkan BPS, tahun 2018 ditutup dengan angka 15,8 juta. Disamping itu wisman mengeluarkan US\$ 1.220 per kepala selama berwisata, per kunjungan atau ASPA (average spending per arrival). Menghabiskan US\$ 1.220 per kedatangan ini merupakan gabungan dari kedatangan 19 pintu utama imigrasi sejumlah 13,3 juta wisman, plus 2,71 juta wisman dari pintu lainnya, termasuk dari festival festival cross border. Jika dijumlahkan mencapai 15.81 juta wisman dan rata-rata US\$ 1.220 perkepala (Kemenparekraf, 2018).

Indonesia memiliki banyak kawasan strategis pariwisata yang memiliki kompetensi sebagai heritage and pilgrim Tourims salah satunya adalah Bali. Menurut Undang Undang Republik Indonesia nomor 10 tahun 2009, "kawasan strategis pariwisata merupakan kawasan yang berfungsi utama pariwisata atau memiliki potensi untuk pengembangan pariwisata yang mempunyai pengaruh penting dalam satu atau lebih aspek, seperti pertumbuhan ekonomi, sosial dan budaya, pemberdayaan sumber daya alam, daya dukung lingkungan hidup, serta pertahanan dan keamanan". Pengembangan pariwisata Bali berlandaskan pada filosofi Tri Hita Karana sebagai bentuk kearifan lokal masyarakat Bali 
serta cara komunikasi yang terbuka dan ramah menjadi ciri khas dari interaksi masyarakat Bali (Andriyani, Djatmika, Sumarlam dan Rahayu, 2019).

Berdasarkan data BPS Provinsi Bali November 2019, tercatat 498.088 kunjungan wisman yang datang langsung ke Provinsi Bali, melalui bandara I Gusti Ngurah Rai sebanyak 493.067 kunjungan, dan kedatangan melalui pelabuhan laut 5.021 kunjungan. Turun -12,32 persen dibandingkan dengan catatan bulan Oktober 2019 (m to m). namun dibandingkan dengan bulan November 2018 (y on y), jumlah ini meningkat 22,46 persen. Dengan persentase wisman kebangsaan Australia (21,14 persen), Tiongkok (15,76 persen), India (6,90 persen), Amerika Serikat (4,60 persen), dan Inggris (4,13 persen) merupakan negara dengan asal wisman paling banyak melakukan kunjungan ke Bali pada bulan November 2019. Tingkat Penghunian Kamar (TPK) hotel berbintang bulan November 2019 tercatat 59,46 persen, turun $-3,84$ poin dibandingkan TPK bulan sebelumnya (m to m) yang tercatat sebesar 63,30 persen. Jika dibandingkan bulan November 2018 (y on y) yang mencapai 55,92 persen, tingkat penghunian kamar di bulan November 2019, tercatat naik 3,54 poin. Rata-rata lama menginap tamu asing dan Indonesia pada hotel berbintang di Bali pada bulan November 2019 tercatat selama 2,71 hari, turun -0,15 poin dibandingkan dengan rata-rata lama menginap tamu pada bulan Oktober 2019 (m to m) yang tercatat selama 2,86 hari. Jika dibandingkan dengan bulan November 2018 (y on y) yang tercatat selama 3,04 hari, rata-rata lama menginap November 2019 turun sedalam 0,33 poin.

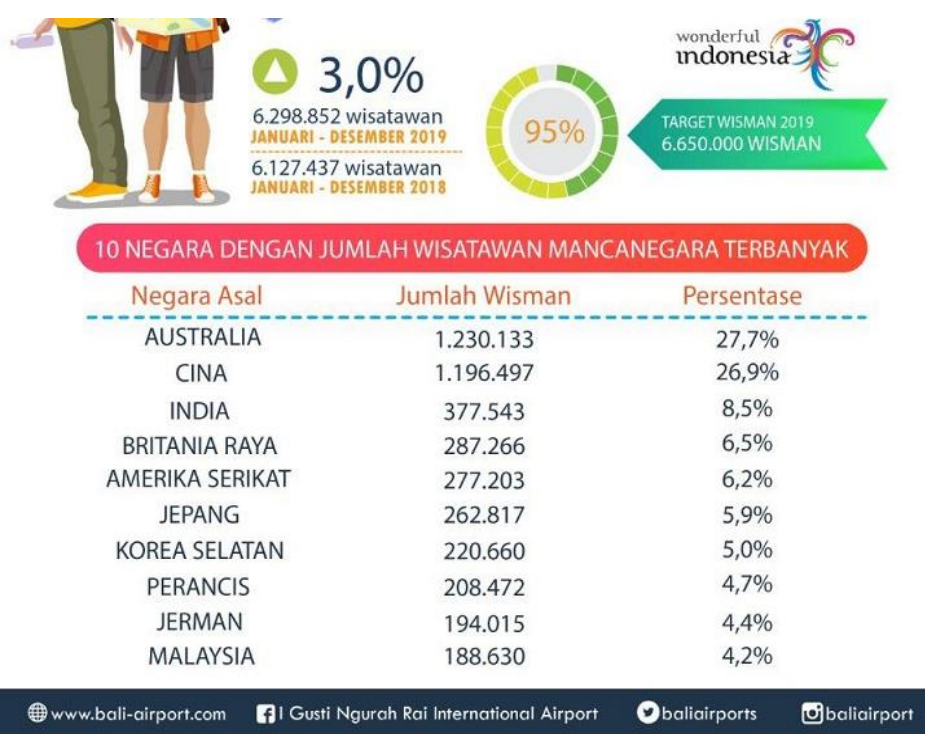

(Sumber: www.bali-airport.com, 2020)

Gambar 1. Jumlah dan Persentase Wisatawan Mancanegara dari Sepuluh Besar Negara Penyumbang Wisman ke Provinsi Bali Selama Tahun 2019 
Permasalahan yang timbul dalam upaya peningkatan pariwisata di Bali adalah mengenai pramuwisata yang berjumlah kurang lebih 900 pramuwisata dengan dua kategori yaitu pramuwisata umum (di tingkat provinsi) dan pramuwisata khusus (lokal) di tingkat kabupaten. Permasalahan yang muncul adalah makin berkembangnya pramuwisata legal (non formal) yang tidak memiliki Kartu Tanda Pengenal Pramuwisata (KTPP). Minimnya jumlah pramuwisata yang mampu berbahasa Jepang juga menjadikan kendala dalam penerjemahan tujuan wisata wisata. Biro Perjalanan Wisata (BPW) pun mulai mempekerjakan native speaker dari luar dengan status visa wisata. Upaya Dinas Pariwisata Provinsi dengan membentuk satgas dalam menertibkan pramuwisata illegal (non formal) dirasa kurang maksimal.

Permasalahan pramuwisata dirasakan juga di desa wisata Kabupaten Bangli. Saat ini kabupaten Bangli sangat membutuhkan kebijakan tata kelola bagi pramuwisata di desa wisatanya. Pramuwisata yang bekerja di desa wisata merupakan pramuwisata khusus yang mendapatkan tugas limpahan dari pramuwisata umum. Pramuwisata umum biasanya bekerja di sektor wisata tingkat provinsi. Tupoksi pramuwisata umum dan khusus adalah sama yaitu sebagai pemandu wisata. Pramuwisata umum seharusnya melimpahkan tugasnya saat pemanduan wisata beralih ke desa wisata. Bangli telah menyiapkan pramuwisata khusus yang bertanggung jawab pada pemanduan di tingkat daerahnya. Tujuannya adalah selain untuk melibatkan peran partisipasi masyarakat lokal dalam pengembangan wisata di daerahnya, juga bertujuan agar pemanduan wisata lebih terarah karena materi wisata di daerah lebih dikuasai oleh pramuwisata khusus atau lokal.

Berkaitan dengan pelibatan masyarakat, partisipasi masyarakat tidak hanya sebatas kontribusi tenaga, waktu, dan materi lokal secara cuma-cuma, untuk mendukung berbagai program dan proyek pembangunan namun juga sebagai suatu keterlibatan secara aktif dalam setiap proses (Drake dan Susan, 1991 dalam Pitana dan Gayatri, 2002). Peran aktif yang dimaksud adalah mulai dari perencanaan, penentuan rancangan, pelaksanaan sampai dengan pengawasan dan penikmat hasilnya (genuine participation) atau dengan kata lain masyarakat sebagai pelaku pariwisata (Slamet, 1993).

Berkembangnya pariwisata di Bali juga berdampak kepada perempuan untuk menempati berbagai profesi, dapat dilihat dari banyaknya tenaga kerja perempuan yang menempati posisi di sektor pariwisata, perempuan juga dipandang lebih telaten, rapi, hati-hati dan efisien, diantara posisi tersebut adalah: humas, sales, Pemasaran, pemelihara rumah, resepsionis, sales tiket, pramusaji, dan pramugari. Hal ini karena dalam melakukan pekerjaan, (Pendit, 2001). Dengan bervariasinya usaha jasa pariwisata, akan memberi kesempatan kepada perempuan untuk bekerja dengan sistem 
penggal/paruh waktu serta usaha yang dilakukan lebih banyak mendekati sektor informasi (Utarini, 2005). Menurut (Fromm, 1996, dalam Bawa, 2004), wanita memiliki motivasi menjadi pengelola pondok, hal ini terkait dengan suatu harapan kehidupan yang lebih baik, Selain itu, adanya harapan terbebas dari kejenuhan seperti ingin mengembangkan dan mengaplikasikan diri sesuai kemampuan dan keahlian, nomor 5 tahun 2016 meningkatkan pendapatan keluarga, juga untuk mengatasi ketimpangan status sehingga dalam keluarga ia tidak dipandang rendah.

\section{METODE}

Untuk mencapai sebuah tujuan, dan tanggapan secara berkelanjutan maupun dapat menyesuaikan terhadap peluang dan ancaman eksternal serta kekuatan dan kelemahan internal yang dapat mempengaruhi organisasi dibutuhkan strategi yang tepat. Sebagai upaya dalam mengembangkan suatu tujuan pariwisata, perencana perjalanan (tourism planner) dapat mengacu kepada dua hal penting pada pengembangan yang saling mendukung, yaitu lingkup pengembangan spasial dan tingkatan pengembangan dari tujuan wisata tersebut (Getz, 1986). Lingkup pengembangan spasial merupakan keharusan untuk memahami dan mengamati latar belakang kontekstual atau lingkungan makro dari tujuan wisata yang akan dikembangkan (Rangkuti 2017). Sedangkan tingkatan pengembangan tujuan wisata yang dimaksud adalah cara pandang atau perspektif planning pengembangan tujuan wisata yang harus berpandangan secara holistik dan menyeluruh (Sunaryo, 2013). Pembangunan Kepariwisataan Budaya Bali diarahkan untuk:

a. Meningkatkan harkat dan martabat, serta memperkukuh jati diri masyarakat Bali;

b. Meningkatkan kesejahteraan masyarakat Bali secara merata dan berkelanjutan; dan

c. Melestarikan lingkungan alam Bali sebagai basis penyangga kehidupan masyarakat dan kebudayaan Bali secara berkelanjutan.

Bali merupakan ikon dan konfigurasi pariwisata Indonesia, Bali telah menjadi salah satu tujuan wisata wisata dunia yang sangat populer. Pariwisata telah menjadi generator penggerak pembangunan perekonomian masyarakat Bali. Disamping itu tekanan terhadap lingkungan akibat pembangunan fisik semakin besar.

Tidak adanya pelimpahan tugas yang jelas dari pramuwisata umum ke khusus juga membutuhkan adanya aturan yang jelas. Pada desa wisata Bangli masih terdapat pramuwisata umum yang melakukan pemanduan wisata. Akibatnya penyampaian tujuan wisata wisata kepada wisatawan kurang maksimal bahkan dimungkinkan terjadi kesalahan pemanduan karena informasi mengenai desa wisata lebih dipahami oleh pramuwisata 
khusus. Secara yuridis pembangunan kepariwisataan provinsi Bali memiliki ketentuan regulasi kepariwisataan. Berikut peraturan perundangan yang mengatur pramuwisata di Bali.

a. Pergub nomor 41 tahun 2009 mengatur tentang tata cara mendapatkan sertifikat pramuwisata, Kartu Tanda Pengenal Pramuwisata (KTTP) dan penggunaan pakaian adat Bali.

b. Peraturan Menteri Pariwisata Republik Indonesia nomor 13 tahun 2015 yang mengatur tentang standar usaha jasa pramuwisata. Aturan ini menyatakan perlunya Sertifikasi Kompetensi dan Sertifikasi Usaha di Bidang Pariwisata demi peningkatan mutu produk, pelayanan dan pengelolaan serta daya saing usaha jasa pramuwisata. Lembaga Sertifikasi Usaha (LSU) Bidang Pariwisata bertugas membuatkan Sertifikat Usaha Jasa Pramuwisata Pariwisata kepada Pemilik Usaha Jasa Pramuwisata yang telah memenuhi Standar sesuai ketentuan peraturan perundang-undangan.

c. Peraturan Daerah Provinsi Bali nomor 5 tahun 2016 tentang pramuwisata menjelaskan bahwa pramuwisata merupakan salah satu komponen penting dalam jasa pariwisata yang sangat berpengaruh terhadap kualitas layanan dan citra pariwisata secara keseluruhan. Maka dari itu perlu penertiban dan peningkatan kualitas pramuwisata terutama tentang penguasaan pengetahuan kebudayaan Bali. Sehingga tugas pramuwisata tidak hanya sebatas memandu tetapi juga sekaligus mendidik wisatawan.

Dari sejumlah peraturan tersebut masih belum ditemui peraturan yang mengatur pramuwisata khusus/lokal. Kebijakan adanya pembagian pramuwisata umum di tingkat provinsi dengan tupoksi melakukan pemanduan di daerah tujuan wisata tingkat provinsi termasuk bertanggung jawab dari penjemputan sampai pengantaran ke desa wisata, serta adanya pramuwisata khusus/lokal yang bertanggung jawab mengambil alih tugas pemanduan dari umum ke desa wisata, menimbulkan permasalahan yang harus dicermati secara perundang undangan. Desa wisata membutuhkan keterlibatan masyarakat lokal untuk menumbuhkan rasa memiliki dan tanggung jawab terhadap kepariwisataan yang ada di daerahnya. Dengan demikian harus ada regulasi yang mengatur kompetensi pemanduan yang professional.

Berdasarkan hal ini maka perlu adanya kegiatan PKM sebagai mediator dalam pengujian tata kelola pramuwisata khusus bentuk langkah awal memperbaiki aktifitas pemanduan dan pemberian servis pada wisatawan. Tujuannya adalah untuk mendukung 
program pengembangan wisata khususnya di tingkat lokal sebagai strategi memaksimalkan keterlibatan masyarakat sehingga tingkat kesejahteraan masyarakat lokal pun meningkat.

\section{HASIL, PEMBAHASAN, DAN DAMPAK}

Regulasi yang diterbitkan oleh Gubernur Provinsi Bali mengenai tata kelola pramuwisata menunjukkan komitmen pemerintah daerah provinsi untuk melakukan penataan secara manajemen bagi para pramuwisata. Pada kenyataannya dengan diterbutkannya regulasi Peraturan Daerah nomor 5 tahun 2016, tidak menyurutkan permasalahan yang ada pada hal pemanduan.

Peraturan Daerah Provinsi Bali No. 5 Tahun 2016 mengatur pramuwisata yang bekerja di tingkat provinsi. Peraturan Daerah memberikan peluang pada para Bupati untuk membuat turunan regulasi pada pasal 5 ayat 2, 3, dan 4 yaitu;

a. Bupati/Walikota menerbitkan Kartu Tanda Pengenal Pramuwisata Khusus setelah melakukan koordinasi dengan Gubernur.

b. Ketentuan mengenai standar jasa pelayanan Pramuwisata Khusus diatur oleh Bupati/Walikota.

c. Ketentuan mengenai Pramuwisata khusus diatur oleh Bupati/ Walikota.

Pada Peraturan Daerah di atas, sangatlah jelas bahwa Gubernur Provinsi Bali menyerahkan tata kelola pramuwisata khusus kepada Bupati/Walikota. Oleh karena itu, Peraturan Bupati sebagai turunan dari Peraturan Daerah untuk memberikan kebijakan pada pemanduan khusus bukan merupakan sutu kewajiban melainkan suatu kebutuhan tiap Kabupaten. Pramuwisata khsusus akan memiliki power saat wisatawan berkunjung di daerah wisata kabupaten. Perlu disepakati batas pelimpahan tugas sebagai bentuk pelimpahan tugas dari pramuwisata umum ke khusus. Tahap awal dari pengkategorian tugas dari pramuwisata adalah penerbitan Kartu Tanda Pengenal Pramuwisata Khusus.

Di tingkat provinsi, pramuwisata umum harus mengikuti serangkaian test untuk mendapatkan kartu tanda pengenal pramuwisata. Test diberikan mengacu pada persoalan pemanduan di tingkat provinsi, misalnya mengenai objek wisata provinsi. Di tingkat kabupaten, perlu dilakukan test bagi pramuwisata khusus dengan lingkup permasalahan yang ada di daerah tujuan wisata kabupaten. Test di tingkat provinsi diberikan oleh Dinas Pariwisata Tingkat Provinsi Bali, sedangkan di tingkat kabupaten pembuatan soal diserahkan pada Dinas Pariwisata tingkat Kabupaten. Pramuwisata yang telah lolos pada test di tingkat kabupaten akan mendapatkan Kartu Tanda Pengenal Pramuwisata Khusus yang diterbitkan oleh Bupati. Pramuwisata Khusus dalam melaksanakan tugas 
kepemanduan wisata di Daerah Tujuan Wisata, wajib menggunakan Kartu Tanda Pengenal Pramuwisata Khusus sesuai dengan tempat Pramuwisata Khusus bertugas.

Masyarakat Bali merupakan masyarakat yang sangat menghargai budayanya. Di Bali tidaklah sulit untuk menemukan rumah penduduk yang masih melestarikan ciri tradisional Bali. Demikian juga dari segi pakaian tradisional. Di daerah wisata banyak ditemui pramuwisata yang menggunakan pakaian adat Bali. Hal ini tentu akan memberikan kesan baik bagi wisatawan. Pramuwisata harus memperhatikan penampilannya agar terlihat menarik. Menarik artinya tidak berlebihan dalam berpenampilan Biasanya pemandu yang berpenampilan menarik, unik, bersih, dan menyenangkan akan disukai wisatawan. Pramuwisata berpakaian adat Bali tertuang dalam Peraturan daerah nomor 5 tahun 2016. tugas pemandu yaitu: "Memakai Kartu Tanda Pengenal Pramuwisata Khusus, Memakai Pakaian Adat Bali, Memandu wisatawan, Memberikan penjelasan dan petunjuk tentang Daerah Tujuan Wisata, jika tidak didampingi pramuwisata umum, pramuwisata khusus membantu menguruskan barang bawaan wisatawan dan membantu keperluan wisatawan di Daerah Tujuan Wisata, Memberikan pertolongan kepada wisatawan yang sakit, mendapat kecelakaan, kehilangan atau musibah di Daerah Tujuan Wisata, Bekerja sama dengan pramuwisata umum".

Dinas Pariwisata yang menaungi para pramuwisata perlu melakukan pembinaan dan pengawasan. Di tingkat Kabupaten, Bupati perlu menunjuk Dinas melaksanakan pembinaan dan pengawasan terhadap Pramuwisata Khusus. Pembinaan berupa pelatihan, bimbingan teknis dan sosialisasi untuk meningkatkan pengetahuan dan keterampilan Pramuwisata Khusus. Pelaksanaan pengawasan akan lebih mengena bila Dinas yang ditunjuk Bupati melakukan pemantauan langsung ke daerah wisata tempat pramuwisata khusus melakukan pemanduan. Hal ini akan memberikan informasi yang riil tentang kinerja pramuwisata khusus sekaligus dapat memahami tingkat kepuasan wisatawan. Perlu ada sanksi dengan aturan tertulis untuk menangani pramuwisata yang tidak menjalankan pemanduan secara benar. Sanksi secara administrasi dapat berupa, Teguran lisan, Teguran tertulis, Pembekuan kartu tanda pengenal pramuwisata khusus, dan/atau Pencabutan Kartu Tanda Pengenal Pramuwisata Khusus.

Kepariwisataan Bali berkembang berlandaskan kepariwisataan budaya. Kepariwisataan ini merujuk kepada ajaran Agama Hindu dan falsafah Tri Hita Karana. Hubungan timbal-balik yang dinamis antara kepariwisataan dan kebudayaan membuat keduanya berkembang secara sinergis, harmonis dan berkesinambungan untuk dapat memberikan kesejahteraan kepada masyarakat, kelestarian budaya dan lingkungan. 
Konsep Tri Hita Karana (THK) sesuai dengan Kode Etik Pariwisata Dunia yang dikembangkan World Tourism Organization (WTO), yakni pengembangan sektor pariwisata dengan melibatkan hubungan interaksi antar manusia dengan manusia, dengan lingkungan, dan dengan budaya. Melalui konsep ini diharapkan kegiatan pariwisata dapat terbagi secara merata di semua lapisan sektor masyarakat dan tercipta pariwisata yang berkelanjutan.

Berkaitan dengan konsep Tri Hita Karana, seorang pramuwisata khusus wajib memahami isi dan falsafah ini. Sehingga pariwisata Bali memiliki kewibawaan secara religi yang wajib dihormati oleh para wisatawan khususnya dari manca negara. Baru baru ini ada berita mengenai seorang turis yang mencuci badannya di tempat yang selayaknya sebagai tempat air suci. Hal ini tentu menyinggung kepercayaan masyarakat Bali. Oleh karena itu pramuwisata perlu diberi edukasi mengenai falsafah Tri Hita Karana dan perlu dilakukan test pemahaman pramuwisata mengenai falsafah yang menjadi ciri khas masyarakat Bali ini. Pramuwisata saat melakukan pemanduan selain memberi penjelasan mengenai objek wisata, perlu juga menjelaskan secara falsafah dari objek wisata tersebut. Hal ini akan meminimalkan permasalahan yang sering terjadi karena ketidaktauan wisatawan terhadap objek yang seharusnya diperlakukan secara ritual.

Berdasarkan tata kelola pramuwisata khusus yang telah diuraikan di atas, berikut bagan model tata kelola pramuwisata khusus:

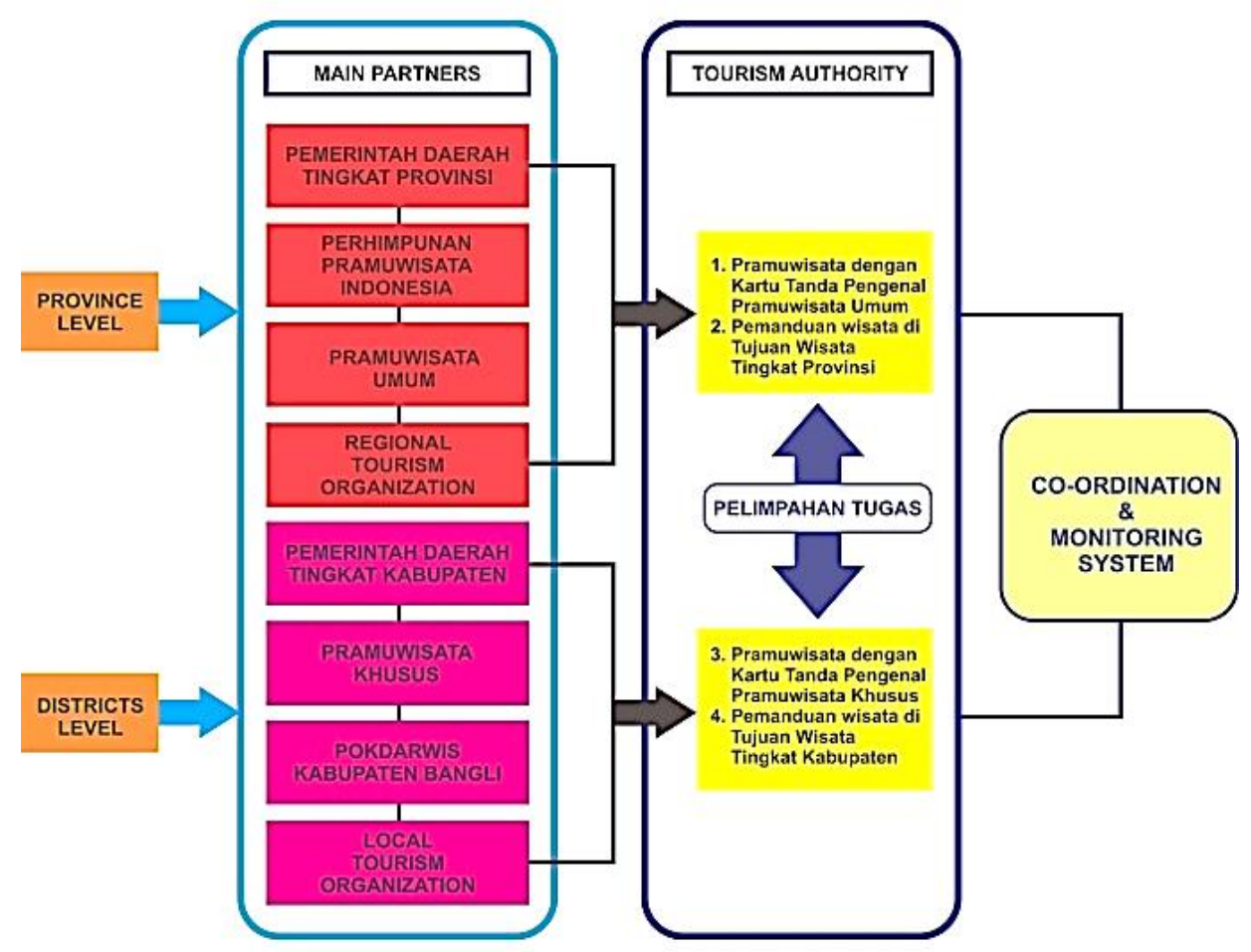

Gambar 2. Model tata Kelola Pramuwisata Khusus 
Bagan model tata kelola pramuwisata umum dan khusus menunjukkan tingkatan wewenang pengaturan pramuwisata. Pada level provinsi, pemerintah daerah tingkat provisi bermitra dengan Himpunan Pramuwisata Indonesia dalam mengelola pramuwisata umum. Sebagian besar wisatawan datang ke daerah tujuan wisata menggunakan biro perjalanan wisata atau regional tourism organitation. Biro perjalanan wisata mempekerjakan para pramuwisata untuk memandu wisatawan, sehingga pramuwisata melakukan pekerjaannya di bawah biro perjalanan. Oleh karena itu, pemerintah daerah tingkat provinsi haruslah bersinergi dengan biro perjalanan wisata. Pada level kabupaten, pemerintah daerah tingkat kabupaten bersinergi dengan tourism-aware group regency yang memiliki kewenangan dalam pengelolaan pariwisata.

Dalam hal pelimpahan pekerjaan pemanduan dari pramuwisata umum ke khusus, dilakukan saat wisatawan masuk ke daerah tujuan wisata kabupaten/pokdarwis. Pada ranah ini pramuwisata umum cukup mengantar di pintu masuk daerah wisata kabupaten, untuk selanjutnya pemanduan wisata diserahkan pada pramuwisata khusus. Perlu adanya koordinasi dan monitoring sistem oleh dinas pariwisata. Hasil dari kordinasi dan monitoring dijadikan dasar evaluasi sekaligus strategi pengembangan pariwisata.

Berikut dokumentasi kegiatan Tata Kelola Pramuwisata Khusus Sebagai Bentuk Pelibatan Masyarakat Lokal

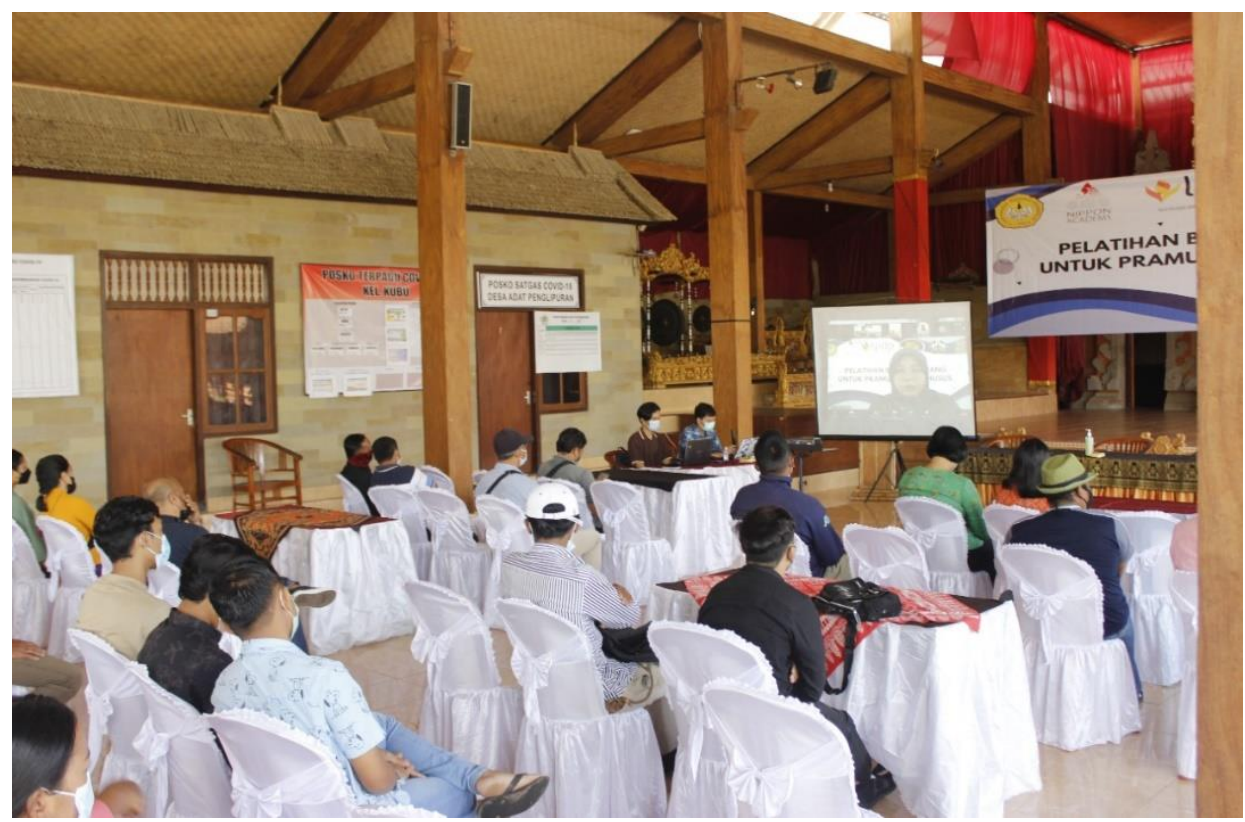

Gambar 3. Sosialisasi Pedoman Menjadi Pramuwisata Profesional ( 18 Maret 2021)

Kegiatan Sosialisasi Pedoman Menjadi Pramuwisata Profesional 20 pramuwisata dibali, karena kondisi pandemi pembicara memberikan pelatihan secara daring, menggunakan aplikasi zoom. 


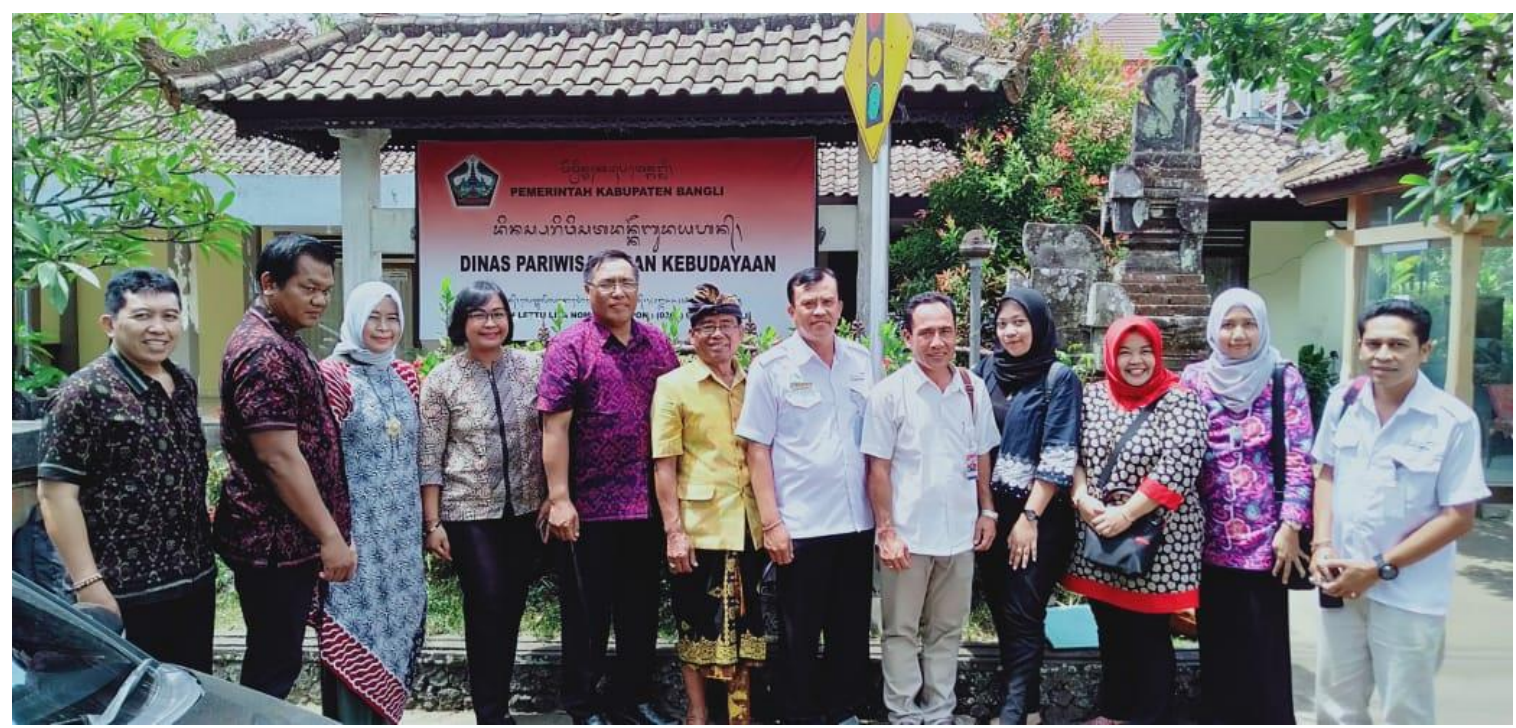

Gambar 4. Peneliti bersama mitra penelitian yaitu himpunan pramuwisata Indonesia DPD Bali (5 September 2019)

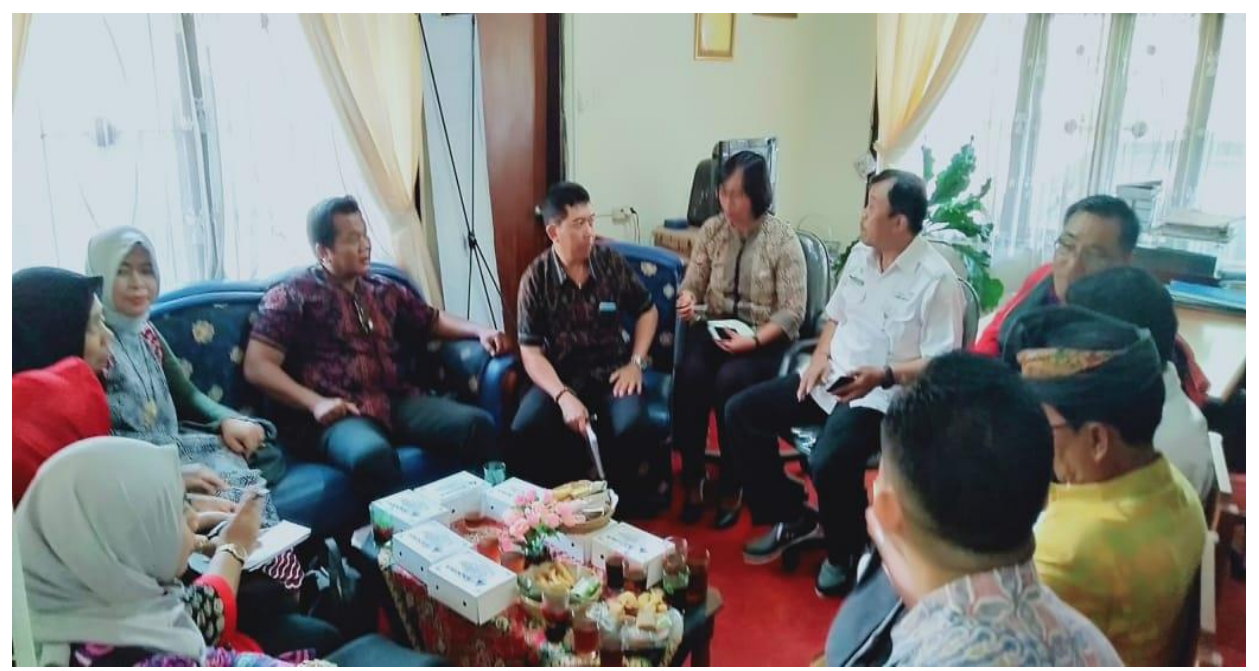

Gambar 5. FGD Mengenai Tata Kelola Pramuwisata khusus bersama Tim Peneliti, HPI DPD Bali, Dinas Pariwisata Kab. Bangli Bangi (6 Spet 2019)

\section{SIMPULAN}

Tata kelola pramuwisata khusus kabupaten Bangli merupakan tata kelola yang disusun berdasarkan kajian pemanduan wisata yang dilakukan oleh pramuwisata baik di tingkat provinsi Bali maupun di tingkat kabupaten. Di tingkat provinsi Bali terdapat peraturan daerah nomor 5 tahun 2016 yang memberikan regulasi bagi pramuwisata dalam menjalankan pemanduan secara profesional. Permasalahan yang muncul dari peraturan daerah ini adalah tidak adanya turunan di tingkat kabupaten sebagai regulasi khusus bagi pelaksanaan pemanduan di daerah tujuan wisata kabupaten. 
Kajian tata kelola ini disusun sebagai dasar pembuatan peraturan bupati kabupaten Bangli mengenai pramuwisata khusus. Model Tata Kelola Pramuwisata memberikan acuan pelaksanaan pemanduan pariwisata dari tingkat provinsi ke tingkat kabupaten. Adanya pelimpahan tugas dari pramuwisata umum ke khusus menunjukkan adanya penataan tugas dan wewenang pramuwisata khusus. Selain itu sebagai tanda pengenal bagi pramuwisata khusus perlu adanya test kopetensi pemanduan tingkat kabupaten. Di bidang kemampuan bahasa asing perlu adanya pembinaan bahasa asing mengingat banyaknya pramuwisata illegal dari orang asing dengan alasan kemampuan bahasa asing dari pramuwisata yang masih rendah. Pelestarian kearifan lokal masyarakat Bali ditunjukkan dengan penggunaan pakaian adat saat melaksanaan pemanduan. Pemanduan pariwisata juga tetap mengangkat filosofi masyarakat Bali yang tercermin pada filosofi Tri Hita Kirana.

\section{UCAPAKAN TERIMAKASIH}

Pengabdian kepada Masyarakat ini dibiayai oleh Lembaga Pengelola Dana Pendidikan (LPDP) Kementerian Keuangan Republik Indonesia melalui Hibah Riset Inovatif Produktif (RISPRO).

\section{DAFTAR PUSTAKA}

Andriyani, A. A. A. D., Djatmika, D., Sumarlam, S., dan Rahayu, E. T. (2019). Pengaruh Lintas Budaya Tingkat Tutur Hormat Keigo melalui Media Sosial antara Driver Guide dan Wisatawan Jepang di Bali. MOZAIK HUMANIORA, 19(1), 1-17. doi: https://doi.org/10.20473/mozaik.v19i1.11976

Bawa, I Wayan, I Wayan Cika. (2004). Bahasa Dalam Perspektif Kebudayaan. Bali: Universitas Udayana

Blaxter, et.al. (2006). How To Research. Buckingham : Open University Press.

Cole, Stroma, 2008. Tourism, Culture and Development: Hopes, Dreams and Realities in East Indonesia. Clevedon: Cromwell Press.

Cooper, Chris, et. Al. (1998). Tourism Principles and Practice (2nded). London: Prentice Hall.

Damanik, Janianton Dan Weber, Helmut F. (2006). Perencanaan Ekowisata. Yogyakarta: Pusbar UGM dan Andi Yogyakarta.

Damardjati. R.S. (1995). Istilah-istilah Dunia Pariwisata. Penerbit Pradnya Paramita. Jakarta

Drake, Susan P. (1991). Local Participation in Ecotourism Projects in Whelan, T. (ed). Nature Tourism: Managing for the Environment. Washington DC: Island Presss 
Getz, D. (1986). Models in tourism planning towards integration of theory and practice. Tourism Management 7 (1), 21-32.

Ismayanti. (2010). Pengantar Pariwisata. Jakarta : PT. Gramedia Widisarana Indonesia.

Kemenparekraf, (2018). Kajian Dampak Sektor Pariwisata terhadap Perekonomian Indonesia. url: https://www.kemenparekraf.go.id/asset_admin/assets/uploads/media/pdf/media_155 4437393_Laporan_Akhir.pdf

Kementerian Pariwisata. (2015). Laporan Akuntabilitas Kinerja Kementerian Pariwisata Tahun 2015. Jakarta : Kementerian Pariwisata.

Lincoln, Yvonna S dan Egon G. Guba. (1985). Naturalistic Inquiry. California : Sage.

Moleong, Lexy. (1989). Metodologi Penelitian Kualitatif. Bandung : Remaja Karya.

Murphy, Peter E. 1985. Tourism : A Community Approach. University Paperbacks : Methuen.

MPR RI. (1978). GBHN Ketetapan MPR RI No. IV/MPR/1978. Yogyakarta : Pustaka Pelajar.

Peraturan Daerah Provinsi Bali Nomor 2 Tahun 2012 tentang Kepariwisataan Bali.

Peraturan Daerah Provinsi Bali Nomor 5 Tahun 2016 tentang Pramuwisata.

Peraturan Menteri Pariwisata Republik Indonesia nomor 13 tahun 2015 tentang Standar Usaha Jasa Pramuwisata.

Pergub nomor 41 tahun 2009 tentang Tata Cara Mendapatkan Sertifikat Pramuwisata, Kartu Tanda Pengenal Pramuwisata (KTTP) dan Penggunaan Pakaian Adat Bali

Pitana, I.G., 2002. "Kebijakan dan Strategi Pemerintah Daerah Bali dalam Pembangunan Pariwisata. Pada Seminar Nasional Pariwisata Bali the Last or the Lost Paradise". Pembangunan Pariwisata yang Berkelanjutan. Denpasar: Universitas Udayana. . (2005). Sosiologi Pariwisata. Yogyakarta : Penerbit Andi.

Purwaningsih, Ratih Melatisiwi. (2012). Pengaruh Kualitas Pelayanan Pemandu Wisata terhadap Kepuasan Wisatawan di Candi Prambanan. Sekolah Pascasarjana Universitas Gadjah Mada. Yogyakarta.

Rangkuti, Freddy. (2017). Analisis SWOT Teknik Membedah Kasus Bisnis. PT Gramedia Pustaka Utama. Jakarta.

Santosa, Budi (2007). Data Mining Teknik Pemanfaatan Data untuk Keperluan Bisnis. Yogyakarta: Graha Ilmu

Sharpley. (1994). Tourism, Tourism and Socciety. Huntingdom: ELM Publication

Sinclair, M. Thea (1998) Tourism and economic development: A survey, The Journal of Development Studies, 34:5, 1-51, doi: https://doi.org/10.1080/00220389808422535 
Slamet, Y. (1993). Pembangunan Masyarakat Berwawasan Partisipasi. Surakarta: Sebelas Maret University Press

Surat Keputusan Menteri Pariwisata, Pos, dan Telekomunikasi Nomor : KM. 82/PW. 102/MPPT-88 tentang Pramuwisata dan Pengatur Wisata.

Suwantoro, Gamal. 2004. Dasar-dasar Pariwisata. Penerbit Andi Yogyakarta

Undang Undang RI Nomor 9 Tahun 1990 Tentang Kepariwisataan

Undang Undang RI Nomor 10 Tahun 2009 tentang Kepariwisataan.

Utarini, Adi. 2005. Kesehatan Wanita Sebuah Perspektif Global. Yogyakarta: Universitas Gajah Mada

Simpala, MM, (2010). Tour Guide: Teori dan Praktik dalam Pariwisata. Jakarta: Indie Publishing.

Sunaryo. (2013). Kebijakan Pembangunan Tujuan wisata Pariwisata, Konsep dan Aplikasinya. Gava Media. Yogyakarta.

Suyitno. (2005). Pemandu Wisata (Tour Guiding). Yogyakarta : Graha Ilmu. 